An ESRC Research Group

Global Poveriy Research Group

\title{
Does performance related pay for teachers improve student performance? Some evidence from India
}

\author{
GPRG-WPS-014
}

\section{Geeta Kingdon and Francis Teal}

Global Poverty Research Group

Website: http://www.gprg.org/ 
Does performance related pay for teachers improve student performance?

Some evidence from India

G Kingdon and F Teal

March 2005

\begin{abstract}
In this paper data from a school survey in India is used to ask whether there is evidence for the payment of performance related pay and whether such pay structures do impact on student achievement. It is shown that - after controlling for student ability, parental background and the resources available - private schools get significantly better academic results by relating pay to achievement; government schools do not. We discuss possible interpretations of this result.
\end{abstract}

Keywords: teacher salaries, efficiency, productivity, economic development

JEL classification: I21

Word count: 7010 .

Acknowledgements: We are indebted to Jim Malcomson and Margaret Stevens for comments on an earlier version of this paper. Måns Söderbom has been very helpful in advice and assistance on the econometric issues. All errors are ours. The research was funded partly by a Wellcome Trust grant, number 053660 and partly by an ESRC grant under the Global Poverty Research Program. 


\section{$1 \quad$ Introduction}

Teachers are a central actor in the learning process that takes place in schools, and teachers' attitudes and effectiveness can vary depending on the incentives they face. Pay structure is potentially an important incentive-tool in the hands of the education policy maker and merit pay proposals have recently been discussed in several countries and applied in some. However, the issue of whether linking teachers' pay to student performance is an effective means of improving that performance has been contentious in educational debates.

Malcomson (1999, p. 2337) in surveying the literature on contract design with respect to performance related pay notes that "the objective measures of performance available are often such poor measures of the performance firms really care about that use of formal performance related pay schemes can be counterproductive". Problems arise from the ability of agents to influence the output measures and the fact that non-measured outputs may be as important as measurable ones. However, in the case of teaching, it may be possible to verify outcomes, if exams can measure output and are marked externally. But verifying whether teacher inputs affect outcomes may still be problematic. Students may be taught by more than one teacher so it will be difficult to link the performance of a particular student to a teacher. Schools differ greatly in the background and quality of their intakes so that exam performance outcomes, which do not control for such student-quality differences, are worthless as a basis for differential payments to teachers. These are some of the reasons advanced for resisting performance related pay in the education sector.

However, Ballou (2001, p.57) calls into question the notion that teaching is inherently unsuited to performance-based pay. He uses data from the US to show that private schools make significantly greater use of merit pay than do public school, even when the comparison is restricted to public systems that most resemble private schools with respect to their size and the 
type of students served. He argues that the reasons for the absence of merit pay are not inherent in the teaching technology, but are due to specific circumstances in public education, notably the opposition of teacher unions. In Britain, while many individual teachers supported the recent introduction of a weak form of performance related pay, the teacher unions have mostly been against it on the grounds that it would create conflict and division among teachers within any given school, undermining collegiality and mutual cooperation. They also argue that it may lead to the exclusion of less able children from school since test results of students will be taken into account in the assessment of merit pay.

A positive correlation between teacher pay and student achievement across schools may simply reflect selection by which high quality teachers work with high quality students. The logic of the case for performance related pay is that improved student achievement causes a rise in pay which, in turn, causes improved student outcomes. In this paper we draw on data from both private and government schools to attempt to assess whether there is a causal relationship between pay and performance or, as the selectivity argument implies, there is simply a correlation induced by both variables being correlated with some other factor.

A very large literature, for both developed and developing countries, has investigated the impact of dimensions of school quality on educational achievement. Hanushek (1986) reviews 147 such achievement production function studies from developed countries and Fuller (1986) reviews 72 such studies from developing countries. More recent studies of the effects of school inputs on student outcomes include Case and Deaton (1999); Angrist and Lavy (1999); Hanushek, Kain, and Rivkin (1999); Betts and Morell (1999); Hanushek et. al. (1996); Kingdon (1996a); and Glewwe and Jacoby (1994). Some of these studies have investigated the impact of teacher salaries on student outcomes, with mixed results. Loeb and Page (2000) focus on explaining why several studies have failed to discover a positive relation between teacher pay 
and student outcomes. To our knowledge, few have addressed the issue of endogeneity in assessing the relationship between pay and achievement, and none appear to have the data that enables a direct comparison of the effect, for similarly aged children, across the private and government sectors.

Even if causality is established as running from higher wage to improved student achievement, the relationship is open to alternative interpretations. One is that a positive impact from wages onto achievement reflects the fact that higher wages likely attract better quality people into the pool for applicants for teaching jobs. A second interpretation is that higher pay raises achievement by raising the effort of existing teachers. In terms of the efficiency wage theory, better paid teachers are likely to work harder in order to increase the chances of retaining their more valuable jobs. The paper will test these alternative explanations of the wage effect on student achievement.

The data and model are set out in section 2. Whether teacher pay is related to performance and the determinants of student achievement are the subject of section 3 . Section 4 considers whether unobserved variables are an important influence on the results. In section 5 we assess possible interpretations which can be given to the results. A final section concludes.

\section{The model and data}

The data is drawn from a survey of pupils and schools in India where public and private school sectors have developed in parallel. The survey collected detailed information on students, their teachers and on various aspects of the school. The dataset was designed to collect information on student, teacher and school quality as well as measuring the factors which determine the outcome for wages and student achievement. Our model consists of two equations: an earnings function for teacher's pay and a production function for student achievement. We outline both 
before turning to the data.

The earnings function for government and private school teachers is of the following form:

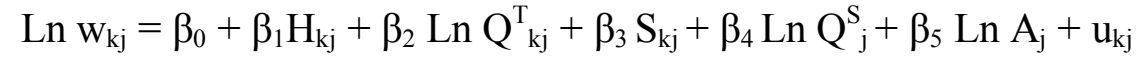

where $\mathrm{w}_{\mathrm{kj}}$ is the gross wage of the $\mathrm{k}_{\mathrm{th}}$ teacher in the $\mathrm{j}_{\mathrm{th}}$ school. This measure of earnings is explained by vectors of variables capturing teacher human capital $\left(\mathrm{H}_{\mathrm{kj}}\right)$, teacher quality $\left(\mathrm{Q}^{\mathrm{T}}{ }_{\mathrm{kj}}\right)$, teacher status $\left(\mathrm{S}_{\mathrm{kj}}\right)$, school quality $\left(\mathrm{Q}_{\mathrm{j}}^{\mathrm{S}}\right.$, ) and the average achievement of students taught by the teacher $\left(\mathrm{A}_{\mathrm{j}}\right)$. It is the significance of this last variable which tests for the existence of performance related pay. We detail below, after we have introduced the data, how we propose to measure these dimensions of human capital and quality.

We next present our achievement function, analogous to a firm production function.

$$
\operatorname{Ln} A_{i j}=\alpha_{0}+\alpha_{1} \operatorname{Ln} R_{i j}+\alpha_{2} \operatorname{Ln}_{Q^{C}}^{C}+\alpha_{3} \operatorname{Ln} Q^{P}{ }_{i j}+\alpha_{4} \operatorname{Ln}^{S}{ }_{j}+\alpha_{5} \operatorname{Ln}_{j}+v_{i j}
$$

where $A_{i j}$ is the achievement score of the $i_{t h}$ student in the $j_{t h}$ school as measured in terms of scores on tests of numeracy and literacy. It is a direct measure of output. Achievement is modeled as being determined by student ability, $\mathrm{R}_{\mathrm{ij}}$; a vector of variables capturing the student and parental attributes, $\mathrm{Q}^{\mathrm{C}}{ }_{\mathrm{ij}}$ and $\mathrm{Q}^{\mathrm{P}}{ }_{\mathrm{ij}}$ respectively; the quality of the school $\mathrm{Q}_{\mathrm{j}}^{\mathrm{S}}$; and finally the wage of the teacher, $\mathrm{w}_{\mathrm{j} .}$. It is the significance of the wage term in this equation which tests whether teacher's wages do impact on achievement.

The data set consists of 902 students surveyed across 20 government-funded and 10 private schools, and a sample of 172 teachers. ${ }^{1}$ The survey collected data on the personal and household characteristics of all students of class 8 (13-14 year olds) in the sample schools and

\footnotetext{
${ }^{1}$ Within the government total, 10 were junior and 10 secondary schools. Within the private sector 5 were junior and 5 were secondary schools. We have included aided schools within the government sector because the state government determines one set of salary scales for both these school types and the state exchequer pays the centrally determined salaries of teachers in both these school types throughout the state. Private schools, on the other hand, are financially autonomous, receive no government assistance, and set their own pay levels individually. The survey was carried out in 1991.
} 
detailed teacher information on only those teachers who taught the sample class. Table 1 describes the variables which we use to model the determinants of wages and achievement. Table 2 shows the means and standard deviations of the variables used in the teacher pay regression. Table 3 gives similar descriptive statistics for variables used in the student achievement function.

Table 2 divides the teachers according to private and government schools. Our measure of pay is the total monthly wage payments made to the teacher. On average, wages in private schools are $38 \%$ lower than those in government-funded schools ${ }^{2}$. Despite this, private school teachers had marginally greater mean number of years of schooling and better results (divisions) in their own board and degree examinations, though they had fewer years of teaching experience, suggesting greater teacher turnover in private schools. This picture is remarkably similar to that in the US, where private school salaries are, on average, $40 \%$ below those in the public school sector but where, despite this, private schools employ a greater proportion of graduates of the better colleges than do public schools, though they also experience considerably higher rates of teacher turnover than those in public schools (Ballou, 1996, p.126) $)^{3}$. Table 2 shows that there is also less dispersion of pay in the public sector. This suggests either greater uniformity in the characteristics of teachers in publicly funded schools or that government-paid teachers' salaries respond much less to idiosyncratic differences between teachers and are more administratively determined.

\footnotetext{
${ }^{2}$ In Kansal's (1990) study on 233 teachers in New Delhi schools, wages in private schools were $42 \%$ lower than in government schools and in Govinda and Varghese's (1993) study of 111 teachers in Madhya Pradesh, they were 45\% lower. Papola and Rodgers (1992) find that in India most small employers (less than 10 workers) do not pay the prescribed minimum wages. Many private junior schools - which are small and typically employ less than 10 teachers - pay salaries that are a fraction of those paid in government funded schools. Mann and Kapoor (1988) find that in all wage employment the differential in private and public sector wages for comparable employees is $31 \%$.

${ }^{3}$ Ballou (1996) finds that US public schools screen out applicants from the best-rated US colleges but that this is not the case in private schools. He considers what plausible explanation can be given for this sub-optimal teacher recruitment policy in public schools and suggests that school administrators may attach much greater importance to applicants' affective characteristics than to cognitive ability. He concludes that "the persistence of sub-
} 
We measure teacher status (S) by three variables: the teacher's union-membership status, whether a teacher has a permanent contract as opposed to a short-term appointment ${ }^{4}$, and teacher gender. So, in the teacher pay equation, i.e. equation (1), $\mathrm{S}=\{$ UNION, PERMANENT, MALE). We measure human capital $(\mathrm{H})$ by three variables: the teacher's years of education, her experience in teaching and whether she received pre-service teacher training. So in the teacher's pay equation $\mathrm{H}=\{$ TEDUYRS, TOTEXP, TRAINING $\}$. We measure the quality of the teacher by four variables: the average division (or grade) that the teacher obtained in his various board examinations and degrees; number of grades/classes he teaches; whether the subject he teaches matches the subject of his own specialization and training; and whether he took most of his board examinations as a regular candidate ${ }^{5}$. So $Q^{\mathrm{T}}=\{$ DIVISION, NCLTAUT, SUBMATCH, REGEXAM $\}$. School quality is measured by three variables: the number of minutes of academic instruction, the resources available to the school and its status as a junior or secondary school. So $\mathrm{Q}^{\mathrm{S}}$ $=\{$ MINACAD, RESOURCE, JHS $\}$. We would argue that this range of variables gives us good controls for the human capital characteristics of the teachers, their quality, and the quality of the school. We turn now to how we measure the characteristics of the students.

Table 3 shows the characteristics of the students, again classified by whether they belong to a government or private school. The achievement measure is the average score on standardized cognitive tests in numeracy and literacy especially designed for this survey by the

optimal practices is likely due to the fact that public schools are quasi monopolies with only limited accountability to the public they serve".

4 The variable 'permanent' measures different aspects of contracts in the public and private sectors. In the public sector, a duly appointed teacher by definition has a job for life, though temporary teachers are occasionally appointed on low pay on an ad hoc basis to fill a vacancy that arises which awaits filling via administrative channels in due course. However, in the private school sector, teachers on an indefinite job contract (as opposed to a fixed term, usually annually renewable, contract) consider themselves as 'permanent'.

${ }^{5}$ Board examinations in India can be taken by an individual either as a regular candidate or 'privately'. People following a particular degree or qualification who are enrolled in college or university are called regular candidates but those who take the examination after self-study (and are not enrolled in college or university for routine attendance of lectures or classes) are called private candidates. Private candidacy involves little or no interaction with a formal teacher to prepare for examination. Working people who wish to enhance their educational qualifications and 
researcher; i.e. the tests were not devised by the schools themselves. The numeracy score varies from 0 to 36 and that for literacy from 0 to 29 , so the maximum possible achievement score for a student is 65 and the minimum 0 . The ability of the student, $\mathrm{R}$ in equation (2), is measured as their score on the Raven's progressive matrices test. This is a test of non-verbal reasoning which has been widely used as an indicator of innate ability or intelligence (Boissiere, Knight and Sabot, 1985; Glewwe and Jacoby, 1994; Appleton, 1995; Alderman et. al., 1996). The test is intended to be independent of schooling ${ }^{6}$. The controls we have for child attributes, $\mathrm{Q}^{\mathrm{C}}$, are the student's age, gender, educational aspirations, hours of study at home per week, minutes taken to travel to school each day, whether child works in vacations, takes private tuition, and number of siblings. So, in equation (2), $\mathrm{Q}^{\mathrm{C}}=\{$ CHAGE, MALE, CEDASP, HSTUDY, TRTIME, VACWRK, TAKESTU, NUMSIB $\}$. There are a large number of controls possible for parental attributes: mother's education, the wealth of the household, number of books in the household, whether parents help the child at home in his homework, and the parents' caste and religion. So $\mathrm{Q}^{\mathrm{P}}$ $=\{$ MEDYRS, WEALTH, BOOKHOM, PARHELP, LOWCASTE, MUSLIM $\}$.

There is clear evidence from Table 3 that private school students come from richer and more educated homes: the wealth index is nearly three times higher in the private sector and the average education of the mothers of students is over 50 per cent higher. They also have higher ability measured by the Raven's test: the test score is 36 in the private and 27 in the government sector. Private schools also have nearly twice the volume of resources per student as government schools and their students get taught for longer. It is clearly possible that government and private schools differ not only in their level of resources and student quality but

those with no nearby access to college are more likely to take examinations privately. Taking exams 'privately' should not be confused with studying in a private school or college.

${ }^{6}$ Appleton (1995) reports that in early critical evaluations of the Raven's progressive matrices test, assessors argued that "it is as nearly culture-free as any other available test is or can be" and that "it may be said to have done as well as possible to avoid the effects of previous learning and established attitudes". More recently there has been some debate about the extent to which the Raven's ability test is exogenous to achievement (Alderman et. al., 1996). 
in their teaching technology. In particular we would expect that if performance related pay is a means of improving student outcomes, for given levels of resources, it will be observed in the private rather than the government sector. We therefore estimate the pay and achievement functions separately for the two sectors.

\section{The Determinants of Teacher Pay and Student Achievement}

Table 4 reports the results of earning functions for teachers for both the government and private sector. In the equations we control for teacher status (the $\mathrm{S}$ vector described above), human capital attributes (the $\mathrm{H}$ vector described above), and teacher and school quality (the $\mathrm{Q}^{\mathrm{T}}$ and $\mathrm{Q}^{\mathrm{S}}$ vectors described above). We ask which of these factors determine pay and whether schools with higher student achievement do pay their teachers more.

Table 4, columns [1] and [3], provide the answer to this question with no allowance for possible endogeneity. While in the government sector unionisation has a positive effect on pay, in the private sector unionised teachers are paid less. Relatively few private teachers are unionised and we interpret this as a quality control effect in private schools, only very poor quality teachers who are unionised work in the private sector. Permanence of job-contract is not rewarded in the government sector but is in the private sector. It is likely that in the public sector permanency of contract is mandated for every teacher but that the private sector offers permanency to attract or retain good teachers. Gender has a small effect on pay in both sectors. In neither sector does teacher education level significantly affect salary. Teacher experience is not rewarded in the private sector but it is in the public sector, with the expected concave relationship. Pre-service teacher training has statistically highly significant but modest payoffs in the private school pay structure but not in the government pay structure. None of the teacher quality variables matter to teacher pay in the government sector, but in the private sector some 
aspects of quality are reasonably significant, given the small sample size. Some aspects of school quality matter a lot. The length of the school week has a positive and significant effect on teacher pay in the private sector but not in the public. Junior High Schools (JHS) in the private sector pay their teachers substantially less than secondary schools but this is not the case in the public sector. Finally, the variable of most interest, after controlling for all others, is the average student achievement variable. There is a highly significant effect from achievement onto pay for private, but not for government, schools. Clearly the two sectors are using very different means of rewarding their teachers.

Before turning to the issue as to whether this result can be given a causal interpretation we consider the OLS results for the student achievement function in Table 5 columns [1] and [3]. These are the OLS estimates for equation (2) where we control for ability, R; the characteristics of the student and their parents, $Q^{C}$ and $Q^{P}$ respectively; and the quality of the school, $Q^{S}$. The student regressors are at the student level while the school variables, including the teacher's pay, are at the school level, i.e. we have taken average pay in the school across all teachers who teach the sample class $X$ students in the school. The reported standard errors are corrected for clustering at the school level. In both private and government schools student ability, as measured by the Raven test, has a highly significant, and virtually identical, affect on achievement. Both student and parental characteristics affect achievement although the parental attributes seem more important for the government than the private sector. In the government sector the volume of school resources, teaching time and non-labor resources matter for achievement, for the private sector they do not. It appears from the OLS results that a different teaching technology is being used between the government and private sectors. These OLS results show that teacher pay has a highly significant effect on achievement for the private, but not government, sector. 
We now turn to the central issue with which we are concerned. Can these results showing that pay and achievement are linked in the private sector be given a causal interpretation? Given the expectation that $\beta_{5}$ in equation (1) and $\alpha_{5}$ in equation (2) are both positive, we would expect the OLS estimate of each to be upwardly biased. The identification of causal effects rests on finding appropriate instruments for average student achievement in the teacher pay regression and for average teacher pay in the student achievement regression. ${ }^{7}$ Given the different levels of aggregation of the two equations, it is not possible to set up a simultaneous equation system.

Table 4 columns [2] and [4] instrument student achievement. We experimented with a range of instruments, choosing as instruments variables from the vector of student characteristics - the student's hours of study at home, educational aspirations, whether he/she does any vacation work or takes private home tuition - which are known to affect achievement and which we assume do not directly affect teacher pay. While this assumption may in principle be challenged, in practice, the Sargan test provides empirical support for the validity of the instruments $^{8}$. Table 5 columns [2] and [4] instrument teacher's pay. Again we experimented choosing as instruments dimensions of the status and human capital of teachers - teacher's experience, gender, union membership and permanent/temporary status ${ }^{9}$. These variables clearly

${ }^{7}$ Two conditions must be fulfilled for the identification of causal effects using instrumental variables (Angrist, Imbens, and Rubin, 1996), for example when testing whether teacher pay has a causal effect on student achievement. Firstly, the correlation of the instrument of teacher pay with the error term in the achievement equation should be zero and, secondly, the covariance of teacher pay and the instrument of teacher pay should be significantly different from zero. Similarly for the case when testing whether schools pay performance-related pay, i.e. when average student achievement is the endogenous variable in the teacher pay regression.

${ }^{8}$ The instruments (hours of study at home, educational aspirations, vacation work, and private tutoring) for student achievement are, in large part, measures of student home life. They could all proxy for parents' interest in education and thus affect teacher pay, especially in private schools where parents have the ability to affect overall spending levels. However, note that we control for school resources, which proxies for parents' ability to pay.

${ }^{9}$ Since the instruments for pupil achievement to be included in the teacher pay equation have to be schoollevel variables, the first stage equation of student achievement is run in the aggregate form, i.e. aggregating all child variables across students within a school. This implies the availability of only 20 school level observations in the government sector and 10 school-level observations in the private sector. Consequently, we were unable to include the whole vector of student variables as our set of instruments. We used the student variables most well correlated with achievement as identifying instruments for achievement. Similarly, teacher characteristics are first averaged over all 
determine pay. While teacher experience could affect student achievement directly, there is less reason to suppose that permanent status would have a direct effect. We use both permanence and gender as our instruments and empirically these variables are accepted as exogenous by the Sargan over-identifying tests reported in Table 5 at the 5 per cent significance level.

Comparing Columns [3] and [4] in both Tables 4 and 5 we see that the effect of instrumenting is to reduce the size of achievement on pay, and that of pay on achievement, but in both cases there remains a significant effect in the private sector. How large is the effect? According to Table 4, an increase in achievement from one standard deviation below the mean to one standard deviation above raises private school teacher pay by $131 \%$. According to Table 5 , increasing private teacher pay from one standard deviation below mean pay to one standard deviation above raises student achievement by $22 \%$.

There appears to be strong evidence both that there is performance related pay in the private sector and that such pay impacts on student achievement. In the next section we consider possible objections to these results.

\section{$4 \quad$ Are unobservables important?}

Our results depend on using variation in teachers' pay across schools. Some examples of performance related pay are within school phenomena. For instance, the paper by Weistroffer et al (2001) discusses merit pay in colleges which creates within college variation in wages. We do not have data that enables us to exploit such variation. It is clearly possible that some unobserved within school factor in the achievement equation is biasing our estimate of the effects of pay onto achievement. We would argue that the most important factors, which would be unobserved in most data sets, are the quality of the school, teacher, and student. Our data set 
has an extensive set of controls for each of these attributes and even with this set of controls there is a clear positive effect of pay onto achievement in private schools.

It could be argued that school-level panel data would be preferable as, by construction, this would control for all the unobserved time invariant characteristics of the school. However, in so far as the relevant teacher pay term in the achievement equation is a relative pay term across schools then it will be a school fixed-effect, so it would be differenced out in panel data. In so far as it is a time-varying factor, using panel data would be preferable only if the measurement error associated with changes were sufficiently small to enable the data to identify changes of achievement with changes in wages. While panel data would enable the analysis to be advanced further, we would argue that our controls for quality are sufficiently comprehensive to make doubtful an interpretation of the positive correlation as due to a common quality factor generating the result. The fact that all the sample schools are in the same city and given the smallness of the sample should make it more difficult to capture any effect of pay on performance, making our finding of an effect more remarkable.

We can address the possibility of bias through omitted student ability still further than we have so far. In the previous section we argued that we had controlled for student quality by direct measures of ability and by numerous variables capturing the parental background of the students. It could be argued that a selection corrected model is required to properly allow for differences in the unobserved characteristics of pupils. As is well known, such models are subject to the problem that the results can be sensitive to the exclusion restrictions that are used to identify the achievement equation. We experimented with a range of exclusion restrictions. The lambda term from the probit was wholly insignificant in all the trials and the size and 
significance of the coefficient of pay was unaffected ${ }^{10}$. This is consistent with our earlier argument about the adequacy of our controls for ability. We interpret this as evidence that unobserved factors are not inducing a correlation between the error term and the instruments. We conclude that this is further evidence that our finding that teachers pay impacts on achievement is causal and not due to the selection of higher quality or more motivated students into private schools.

\section{$5 \quad$ Interpreting the results for achievement}

We have argued that for private schools there is convincing evidence for causation running from teacher's pay to achievement. We consider two potential interpretations of this result. The most popular explanation is that salaries proxy for teacher quality: raising wages encourages better quality candidates to apply for teaching positions, thereby raising the average quality of teachers. A second interpretation comes from efficiency wage theory. Under this, higher wages improve student achievement by increasing teacher effort at any given level of teacher quality.

We test first for the teacher quality interpretation. We have already included as a measure of teacher quality the average division (or grade) that the teacher obtained in her various board/degree examinations. It is arguable that there are several other dimensions of teacher quality, such as years of education, experience and pre-service training which are important. If we find that inclusion of other teacher quality measures in the achievement production function reduces the size and significance of the wage coefficient, then the effect of wages on achievement can be interpreted as occurring via higher wages raising teacher quality. We find, however, that inclusion of teacher quality controls in the achievement function in Table

10 The results are available from the authors. Kingdon's (1996b) study found that when controlling for selectivity of students into private and public schools, the selectivity term lambda was weakly significant ( $\mathrm{t}=1.8$ in private and $\mathrm{t}=-1.8$ in the government) achievement functions when there were no controls for any school or teacher variables. 
6 , column [1], does not reduce the coefficient on the wage variable ${ }^{11}$. This suggests that wage is not capturing the effect of teacher quality.

Can the estimated achievement function be given an interpretation in terms of the literature on efficiency wages? Efficiency wage theory predicts that when monitoring worker effort is difficult, paying a worker higher than his opportunity wage elicits greater worker effort and higher effort is labor augmenting. In the test for efficiency wages that have used production functions (e.g. Levine, 1992) the Solow condition has been used to test whether the coefficient on labor input is the same as the coefficient on the wage term ${ }^{12}$. We can carry out a similar test with our model. The test for efficiency wages is that the coefficient on the wage term should equal the coefficient on the time input per student. In Table 6 column [2] we report the results of using a measure of labor input per student (PPMINACAD), which is equal to the minutes of academic instruction provided per week (MINACAD) divided by class size (CLNUM). We test the restriction implied by this particular form of the test for efficiency wages is met, namely that the coefficient on PPMINACAD and LNPAY are the same. It is clear from the regression that the restriction is accepted. This result permits the interpretation that in the private sector not only does pay impact on achievement but the private sector sets wages to elicit the optimal level of effort from the teachers.

\footnotetext{
${ }^{11}$ While the 2SLS result in Table 5 tested for the possibility that the OLS coefficient on LNPAY is high due to endogeneity bias, the logic here is to see whether the OLS coefficient on LNPAY in Table 5 is high due to omitted variable bias, i.e. due to the fact that aspects of teacher quality are missing in Table 5. We experimented with including several different teacher quality variables other than total experience, years of teacher training and average division/grade obtained in the teacher's various examinations. These were years of teacher's education, square of teaching experience, subject matches the one taught, and whether teacher took exams as a regular candidate. It was not possible to include all of these variables together given the fewness of degrees of freedom as there are only 10 private schools in the sample. In order to conserve degrees of freedom we collapsed the two separate variables MINACAD and CLNUM into one variable, PPMINACAD which is per pupil minutes of academic instruction per week. In none of these experiments did the coefficient on wage fall below 0.30 and it continued to be significant at the $1 \%$ level.

${ }^{12}$ According to efficiency wage theory, firms that pay high wages are predicted to have higher productivity from high worker effort, low turnover etc. and employers will raise wages until the marginal benefit of higher wages (in terms of increased productivity) balances the increase in the wage bill. The test used by Levine and replicated here
} 


\section{$6 \quad$ Summary and Conclusions}

This paper has sought to address three issues. Firstly, it has examined whether teacher pay is responsive to measures of student performance, i.e. whether schools pay teachers performance related pay. Secondly, it has asked whether higher teacher pay does raise student learning outcomes. Thirdly, it has considered the interpretations that can be given to the findings. Clearly our results in this paper need to be treated with caution. In any comparison across schools the possibility that results are sensitive to the unobservable characteristics of the school is important. We do not have panel data so we cannot use a school dummy to control for all the time invariant effects of the school. However our data does allow controls for what have been regarded as the most important differences across schools, such as resources, teacher quality, student ability and home background.

We have found that private schools do relate pay to teacher's performance as measured by student achievement and that achievement is improved by increasing teacher's pay. We considered two interpretations for this result. The first was that higher wages proxy for higher quality teachers, the second was that higher wages motivate higher teacher effort had support in the data. We have argued that there is no evidence for the first of these interpretations and some for the second. We interpret this as evidence for an efficiency wage pay structure in Indian private education. Monitoring of teacher effort is difficult and relative pay is effective at eliciting greater effort: performance related pay for teachers in private schools in India does improve student performance.

It would be wrong to surmise from the results of this paper that increasing teacher salaries across-the-board is a good way of motivating teacher effort. Under the efficiency wage hypothesis, there must be fear of losing a well-paid job in order for higher wages to elicit higher 
effort. In private schools, the flexibility of managers to set wages and dismiss lax teachers means that efficiency wages are an incentive lever that managers can use to enhance teacher incentives. Since government-funded teaching jobs in India are mostly permanent contracts with little chance of dismissal, efficiency wages are not available as an effort-motivating device in the public school sector.

to pay for themselves. 
TABLE 1 VARIABLE Definitions

\begin{tabular}{|c|c|}
\hline \multicolumn{2}{|l|}{ Teacher status } \\
\hline UNION & Member of a teacher union $\mathrm{Y}=1 ; \mathrm{N}=0$ \\
\hline PERMANENT & Permanent status $\mathrm{Y}=1 ; \mathrm{N}=0$ \\
\hline TESEX & Teacher is male $\mathrm{Y}=1 ; \mathrm{N}=0$ \\
\hline \multicolumn{2}{|c|}{$\underline{\text { Teacher human capital }}$} \\
\hline TEDUYRS & Teacher's education in years \\
\hline TOTEXP & Teaching experience in years \\
\hline EXPSQ & Experience squared \\
\hline TRAINING & Pre-service Training $\mathrm{Y}=1 ; \mathrm{N}=0$ \\
\hline \multicolumn{2}{|l|}{ Teacher quality } \\
\hline DIVISION & $\begin{array}{l}\text { Index of teacher quality. It is the average division/grade she obtained in her various degree and board } \\
\text { exams, after assigning a value of } 3 \text { to first, } 2 \text { to second and } 1 \text { to third division. }\end{array}$ \\
\hline NCLTAUT & Number of grades taught \\
\hline SUBMATCH & Teaches subject of her specialization $\mathrm{Y}=1 ; \mathrm{N}=0$ \\
\hline REGEXAM & Teacher took most of her board exams as a Regular candidate? $\mathrm{Y}=1 ; \mathrm{N}=0$ \\
\hline \multicolumn{2}{|l|}{$\underline{\text { Teacher pay }}$} \\
\hline GROSSPAY & Pay (rupees per month) \\
\hline LNPAY & Log of pay \\
\hline \multicolumn{2}{|l|}{ School quality } \\
\hline JHS & Junior high school $=1$; Secondary school $=0$ \\
\hline MINACAD & Minutes of academic instruction per week \\
\hline CLNUM & Class size \\
\hline RESOURCE & $\begin{array}{l}\text { Index of school resources. The index was constructed by giving a value of } 1 \text { for each of seventeen } \\
\text { facilities such as availability of desks and chairs, blackboards, chalk, charts, playground, toilet, drinking } \\
\text { water, musical instruments and educational equipment such as overhead projector, cassette recorder, } \\
\text { computer, video cassette player, etc. }\end{array}$ \\
\hline \multicolumn{2}{|r|}{ 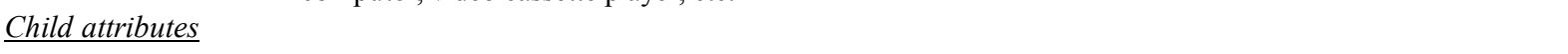 } \\
\hline ACHIEVE & Student's achievement score (total on numeracy and literacy tests) \\
\hline CHAGE & Child's age (in months) \\
\hline MALE & Child's gender MALE $=1$; FEMALE $=0$ \\
\hline CEDASP & $\begin{array}{l}\text { Child's educational aspirations: index from } 1 \text { to } 6 \text { of the highest level to which child aspires, e.g. } 1=\text { up to } \\
\text { grade } 8 ; 2=\text { up to grade } 10 ; 4=\text { first degree, etc. }\end{array}$ \\
\hline HSTUDY & Weekly hours of home study \\
\hline TRTIME & Travel time to school (minutes) \\
\hline VACWRK & Child works out of school hours \\
\hline TAKESTU & Student has private home tuition \\
\hline NUMSIB & Number of siblings \\
\hline \multicolumn{2}{|l|}{ Child ability } \\
\hline SRAVEN & Score on Raven's test of ability or intelligence \\
\hline \multicolumn{2}{|c|}{ Parental attributes } \\
\hline PARHELP & Parents help with studies at home $\mathrm{Y}=1 ; \mathrm{N}=0$ \\
\hline MEDYRS & Mother's education in years \\
\hline MEDYRSQ & MEDYRS squared \\
\hline WEALTH & $\begin{array}{l}\text { Index of household wealth. The variable was constructed by assigning the following values to owned } \\
\text { assets: } C \text { ar }=50 \text {, scooter }=15 \text {, video }=15 \text {, fridge }=6 \text {, telephone }=5, T V=3 \text {, tape recorder, gas cooker }=2 \text { each } \\
\text { and radio, bed(s), bicycle, and clock }=1 \text { each. }\end{array}$ \\
\hline WEALTHSQ & WEALTH squared \\
\hline BOOKHOM1 & Less than or equal to 50 books in the house $\mathrm{Y}=1 ; \mathrm{N}=0$ \\
\hline BOOKHOM2 & More than 50 books in the house $\mathrm{Y}=1 ; \mathrm{N}=0$ \\
\hline ВООКНОМ3 & More than 100 books in the house $\mathrm{Y}=1 ; \mathrm{N}=0$ \\
\hline LOWCASTE & Belongs to low caste $\mathrm{Y}=1 ; \mathrm{N}=0$ \\
\hline MUSLIM & Religion is Muslim $\mathrm{Y}=1 ; \mathrm{N}=0$ \\
\hline
\end{tabular}


Table 2 Teacher Pay Equation Variables

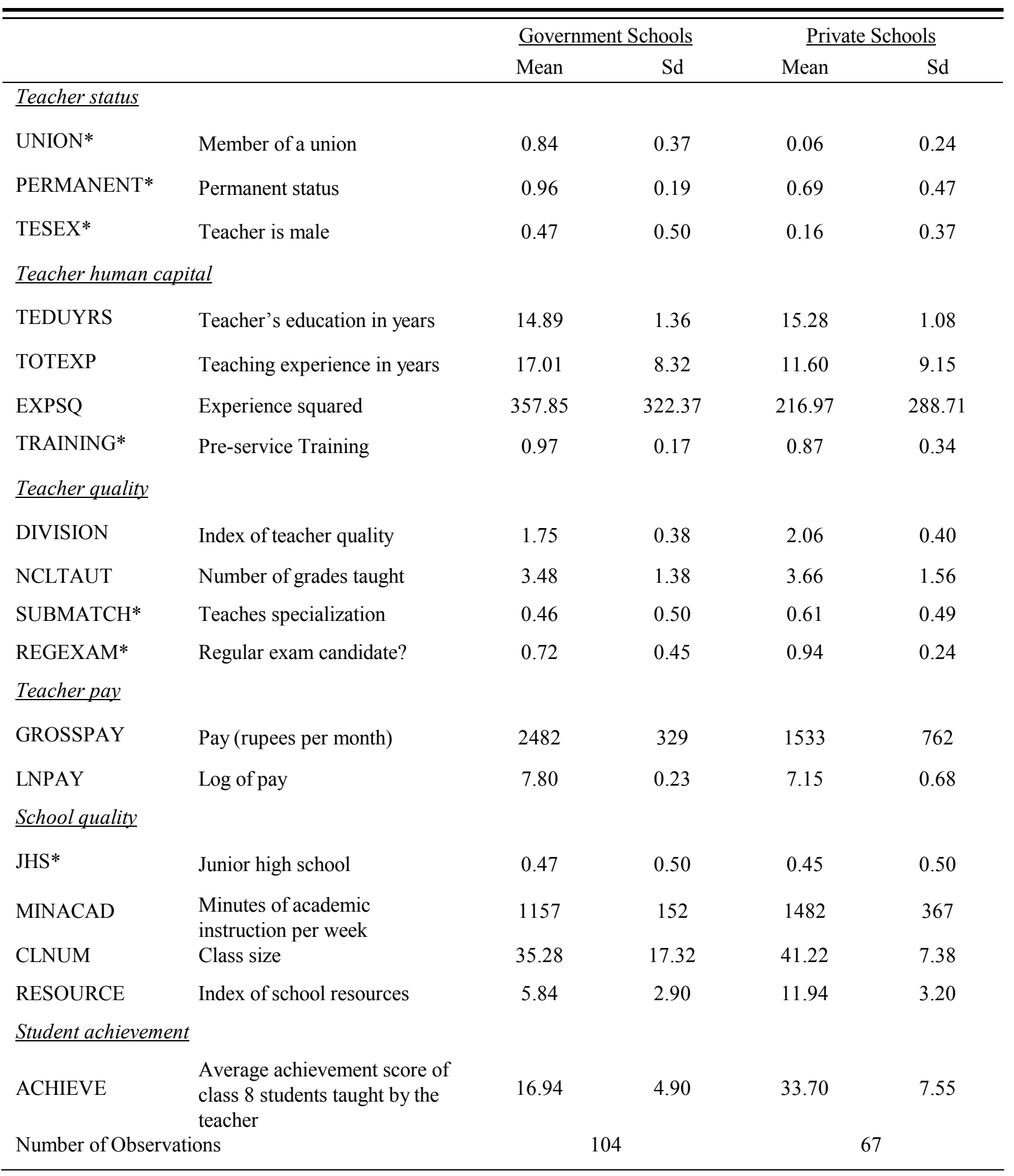

Note: Variables marked with an asterisk $(*)$ are $0 / 1$ variables so that their mean represents the proportion of 1 's. 
TABLe 3 STUdent AChIEVEMENT EQUation VaRIABLES

\begin{tabular}{|c|c|c|c|c|c|}
\hline & & \multicolumn{2}{|c|}{ Govt. } & \multicolumn{2}{|c|}{ Private } \\
\hline & & Mean & $\mathrm{Sd}$ & Mean & $\mathrm{Sd}$ \\
\hline \multicolumn{6}{|c|}{ Child achievement } \\
\hline ACHIEVE & Student's achievement score & 19.00 & 8.38 & 33.79 & 10.5 \\
\hline \multicolumn{6}{|l|}{$\underline{\text { Child ability }}$} \\
\hline SRAVEN & Score on Raven's ability test & 26.87 & 10.10 & 36.03 & 10.6 \\
\hline \multicolumn{6}{|l|}{$\underline{\text { Child attributes }}$} \\
\hline CHAGE & Child's age (in months) & 163.91 & 14.58 & 164.31 & 11.1 \\
\hline MALE* & Proportion of male students & 0.46 & 0.50 & 0.63 & 0.5 \\
\hline CEDASP & Child's educational aspirations & 4.23 & 1.38 & 5.06 & 1.1 \\
\hline HSTUDY & Weekly hours of home study & 19.69 & 10.16 & 24.51 & 10.7 \\
\hline TRTIME & Travel time to school (minutes) & 17.48 & 11.73 & 17.76 & 11.93 \\
\hline VACWRK* & Child works out of school hours & 0.18 & 0.38 & 0.09 & 0.29 \\
\hline TAKESTU* & Student has private home tuition & 0.37 & 0.48 & 0.28 & 0.45 \\
\hline NUMSIB & Number of siblings & 4.46 & 1.70 & 3.28 & 1.45 \\
\hline \multicolumn{6}{|c|}{$\underline{\text { Parental attributes }}$} \\
\hline PARHELP* & Parents help with studies at home & 0.56 & 0.50 & 0.63 & 0.48 \\
\hline MEDYRS & Mother's education in years $/ 10$ & 0.71 & 0.46 & 1.11 & 0.45 \\
\hline MEDYRSQ & MEDYRS squared & 0.71 & 0.64 & 1.43 & 0.81 \\
\hline WEALTH & Index of household wealth/10 & 1.41 & 1.09 & 3.95 & 2.35 \\
\hline WEALTHSQ & WEALTH squared & 3.18 & 5.24 & 21.09 & 21.5 \\
\hline BOOKHOM $2 *$ & More than 50 books in the house & 0.27 & 0.44 & 0.26 & 0.44 \\
\hline BOOKHOM $3 *$ & More than 100 books in the house & 0.20 & 0.40 & 0.44 & 0.50 \\
\hline LOWCASTE* & Belongs to low caste & 0.19 & 0.40 & 0.04 & 0.20 \\
\hline MUSLIM* & Religion is Muslim & 0.29 & 0.45 & 0.12 & 0.32 \\
\hline \multicolumn{6}{|c|}{$\underline{\text { Teacher variables }}$} \\
\hline DIVISION & Index of teacher quality & 1.77 & 0.20 & 2.05 & 0.21 \\
\hline LNPAY & Log of gross pay & 7.80 & 0.13 & 7.12 & 0.65 \\
\hline \multicolumn{6}{|l|}{$\underline{\text { School quality }}$} \\
\hline JHS* & Junior High School & 0.29 & 0.46 & 0.51 & 0.50 \\
\hline MINACAD & Minutes of academic instruction per week & 1161.47 & 146.14 & 1454.78 & 329.30 \\
\hline CLNUM & Class size of the sample class 8 & 44.11 & 16.49 & 41.03 & 8.23 \\
\hline PPMINACAD & $\begin{array}{l}\text { Per pupil minutes of academic instruction } \\
\text { per week (MINACAD / CLNUM) }\end{array}$ & 31.63 & 18.72 & 37.04 & 11.27 \\
\hline RESOURCE & Index of school resources & 6.87 & 2.79 & 11.96 & 3.23 \\
\hline \multicolumn{2}{|c|}{ Number of observations } & \multicolumn{2}{|c|}{542} & \multicolumn{2}{|c|}{360} \\
\hline
\end{tabular}

Note: Variables marked with an asterisk (*) are 0/1 variables so that their mean represents the proportion of 1 's. 
Table 4 Ln (Teachers Pay)

\begin{tabular}{|c|c|c|c|c|c|c|c|c|}
\hline \multirow[b]{3}{*}{ INTERCEPT } & \multicolumn{4}{|c|}{ GOVT. } & \multicolumn{4}{|c|}{ PRIVATE } \\
\hline & \multicolumn{2}{|c|}{$\begin{array}{c}\text { OLS } \\
{[1]} \\
\end{array}$} & \multicolumn{2}{|c|}{$\begin{array}{l}\text { IV } \\
{[2]} \\
\end{array}$} & \multicolumn{2}{|c|}{$\begin{array}{c}\text { OLS } \\
{[3]}\end{array}$} & \multicolumn{2}{|c|}{$\begin{array}{l}\text { IV } \\
{[4]}\end{array}$} \\
\hline & 6.87 & {$[7.5]^{* * *}$} & 6.75 & {$[7.2]^{* * *}$} & -0.06 & {$[0.1]$} & -0.49 & {$[0.4]$} \\
\hline \multicolumn{9}{|l|}{ Teacher status } \\
\hline UNION & 0.06 & {$[2.2]^{* *}$} & 0.06 & {$[2.2]^{* *}$} & -0.54 & {$[4.0]^{* * *}$} & -0.53 & {$[3.7]^{* * *}$} \\
\hline PERMANENT & 0.38 & {$[1.4]$} & 0.38 & {$[1.3]$} & 0.31 & {$[3.5]^{* * *}$} & 0.30 & {$[3.3]^{* * *}$} \\
\hline TESEX & -0.06 & {$[1.8]^{*}$} & -0.06 & {$[1.8]^{*}$} & -0.07 & {$[1.8]^{*}$} & -0.08 & {$[2.3]^{* *}$} \\
\hline \multicolumn{9}{|c|}{$\underline{\text { Teacher human capital }}$} \\
\hline TEDUYRS/100 & 0.69 & {$[0.9]$} & 0.79 & {$[1.1]$} & 1.08 & {$[0.8]$} & 1.61 & {$[0.9]$} \\
\hline TOTEXP & 0.02 & {$[2.9]^{* * *}$} & 0.02 & {$[3.0]^{* * *}$} & -0.01 & {$[0.8]$} & -0.01 & {$[0.8]$} \\
\hline EXPSQ/1000 & -0.47 & {$[2.5]^{* *}$} & -0.46 & {$[2.5]^{* *}$} & 0.39 & {$[1.3]$} & 0.42 & {$[1.2]$} \\
\hline TRAINING & 0.60 & {$[1.5]$} & 0.59 & {$[1.5]$} & 0.17 & {$[4.2]^{* * *}$} & 0.16 & {$[4.4]^{* * *}$} \\
\hline \multicolumn{9}{|l|}{$\underline{\text { Teacher quality }}$} \\
\hline Ln (DIVISION) & 0.07 & {$[0.5]$} & 0.12 & {$[0.5]$} & -0.76 & {$[0.9]$} & -0.52 & {$[0.6]$} \\
\hline NCLTAUT & -0.01 & {$[1.1]$} & -0.01 & {$[1.1]$} & -0.02 & {$[1.7]$} & -0.02 & {$[1.7]$} \\
\hline SUBMATCH/100 & 0.32 & {$[0.1]$} & 0.22 & {$[0.1]$} & 4.91 & {$[1.5]$} & 5.48 & {$[1.6]$} \\
\hline REGUEXAM & -0.04 & {$[0.8]$} & -0.04 & {$[0.9]$} & 0.19 & {$[0.9]$} & 0.22 & {$[1.1]$} \\
\hline \multicolumn{9}{|l|}{$\underline{\text { School quality }}$} \\
\hline JHS & -0.07 & {$[1.6]$} & -0.09 & {$[1.2]$} & -0.47 & {$[3.5]^{* * *}$} & -0.45 & {$[2.9]^{* *}$} \\
\hline Ln (MINACAD) & -0.09 & {$[0.7]$} & -0.06 & {$[0.5]$} & 0.27 & {$[1.7]$} & 0.38 & {$[1.9]^{*}$} \\
\hline Ln (RESOURCE) & -0.05 & {$[1.6]$} & -0.04 & {$[1.3]$} & 0.05 & {$[0.3]$} & 0.11 & {$[0.5]$} \\
\hline \multicolumn{9}{|l|}{$\underline{\text { Student achievement }}$} \\
\hline Ln (ACHIEVE) & 0.17 & {$[1.3]$} & 0.11 & {$[0.7]$} & 1.52 & {$[5.8]^{* * *}$} & 1.30 & {$[3.2]^{* * *}$} \\
\hline $\mathrm{N}$ & 104 & & 104 & & 67 & & 67 & \\
\hline $\mathrm{R}^{2}$ & 0.56 & & 0.55 & & 0.95 & & 0.95 & \\
\hline Sargan [p value] & & & 0.15 & & & & 0.22 & \\
\hline
\end{tabular}

Robust t-values are in [ ] parentheses, allowing for correlation between observations from the same school. In column [2] the instruments used for Ln(ACHIEVE) were CHAGE, HSTUDY and CEDASP. In column [4] the instruments used for Ln(ACHIEVE) were VACWRK and TAKESTU.

* represents significance at the $10 \%$ level, ${ }^{* *}$ at the $5 \%$ level, and $* * *$ at the $1 \%$ level.

The $\mathrm{p}$ value for the Sargan test is based on non-robust standard errors. 
Table 5 Ln (STUdent AChiEVement)

\begin{tabular}{|c|c|c|c|c|c|c|c|c|}
\hline \multirow[b]{3}{*}{ INTERCEPT } & \multicolumn{4}{|c|}{ GOVT. } & \multicolumn{4}{|c|}{ PRIVATE } \\
\hline & \multicolumn{2}{|c|}{$\begin{array}{c}\text { OLS } \\
{[1]}\end{array}$} & \multicolumn{2}{|c|}{$\begin{array}{c}\text { 2SLS } \\
{[2]}\end{array}$} & \multicolumn{2}{|c|}{$\begin{array}{c}\text { OLS } \\
{[3]}\end{array}$} & \multicolumn{2}{|c|}{$\begin{array}{c}\text { 2SLS } \\
{[4]}\end{array}$} \\
\hline & -1.55 & {$[0.9]$} & --4.60 & {$[1.0]$} & -0.05 & {$[0.1]$} & -0.41 & {$[0.6]$} \\
\hline \multicolumn{9}{|l|}{$\underline{\text { Student ability }}$} \\
\hline Ln (SRAVEN) & 0.26 & {$[4.2]^{* * *}$} & 0.26 & {$[4.3]^{* * *}$} & 0.24 & {$[6.4]^{* * *}$} & 0.25 & {$[7.7]^{* * *}$} \\
\hline \multicolumn{9}{|l|}{$\underline{\text { Student attributes }}$} \\
\hline CHAGE/100 & -0.43 & {$[2.7]^{* *}$} & -0.43 & {$[2.6]^{* *}$} & -0.21 & [0.9] & -0.22 & [0.9] \\
\hline MALE & 0.10 & {$[2.1]^{* *}$} & 0.11 & {$[2.8]^{* *}$} & 0.17 & {$[3.3]^{* * *}$} & 0.15 & {$[2.8]^{* *}$} \\
\hline CEDASP/100 & -0.62 & {$[0.6]$} & -0.90 & {$[0.9]$} & 2.77 & {$[1.5]$} & 2.96 & {$[1.6]$} \\
\hline HSTUDY/100 & 0.52 & {$[2.3]^{* *}$} & 0.44 & {$[1.5]$} & 0.34 & {$[3.8]^{* * *}$} & 0.29 & {$[3.1]^{* *}$} \\
\hline TRTIME/100 & 0.14 & {$[0.7]$} & 0.17 & {$[0.9]$} & 0.00 & {$[0.0]$} & 0.00 & {$[0.1]$} \\
\hline VACWRK & -0.09 & {$[1.3]$} & -0.10 & {$[1.5]$} & -0.10 & {$[2.0]^{*}$} & -0.10 & {$[2.1]^{*}$} \\
\hline TAKESTU/100 & -1.80 & {$[0.4]$} & -1.41 & {$[0.3]$} & -8.40 & {$[4.2]^{* * *}$} & -8.53 & {$[4.6]^{* * *}$} \\
\hline NUMSIB/100 & 0.12 & {$[0.1]$} & 0.24 & {$[0.2]$} & -3.49 & {$[2.5]^{* *}$} & -3.80 & {$[2.6]^{* *}$} \\
\hline \multicolumn{9}{|l|}{$\underline{\text { Parental attributes }}$} \\
\hline PARHELP/100 & -3.90 & {$[1.6]$} & -3.77 & {$[1.5]$} & -1.33 & {$[0.3]$} & -2.37 & {$[0.6]$} \\
\hline MEDYRS & -0.10 & {$[1.1]$} & -0.10 & {$[1.0]$} & -0.07 & {$[0.9]$} & -0.04 & {$[0.5]$} \\
\hline MEDYRSQ/100 & 0.07 & {$[1.0]$} & 6.42 & {$[0.9]$} & 0.04 & {$[1.1]$} & 0.03 & {$[0.8]$} \\
\hline WEALTH & 0.16 & {$[2.7]^{* *}$} & 0.17 & {$[2.7]^{* *}$} & 0.03 & {$[0.9]$} & 0.04 & {$[1.0]$} \\
\hline WEALTHSQ/100 & -2.29 & {$[2.1]^{*}$} & -2.39 & {$[2.1]^{*}$} & -2.20 & {$[0.7]$} & -2.70 & {$[0.9]$} \\
\hline BOOKHOM2 & 0.06 & {$[1.3]$} & 0.06 & {$[1.3]$} & 0.00 & {$[0.1]$} & 0.01 & {$[0.3]$} \\
\hline BOOKНОМ3 & 0.09 & {$[2.7]^{* *}$} & 0.09 & {$[2.5]^{* *}$} & 0.03 & {$[0.8]$} & 0.04 & {$[1.1]$} \\
\hline LOWCASTE & -0.16 & {$[3.3]^{* * *}$} & -0.15 & {$[2.6]^{* *}$} & -0.03 & {$[0.4]$} & -0.02 & {$[0.2]$} \\
\hline MUSLIM & -0.05 & {$[1.2]$} & -0.02 & {$[0.3]$} & 0.01 & {$[0.2]$} & 0.01 & {$[0.3]$} \\
\hline \multicolumn{9}{|c|}{ School and teacher quality } \\
\hline JHS & -0.28 & {$[4.9]^{* * *}$} & -0.21 & {$[2.0]^{*}$} & 0.34 & {$[4.4]^{* * *}$} & 0.34 & {$[4.2]^{* * *}$} \\
\hline Ln (DIVISION) & 0.53 & {$[2.1]^{*}$} & 0.0 .34 & {$[1.0]$} & 1.69 & {$[3.2]^{* * *}$} & 2.08 & {$[4.0]^{* * *}$} \\
\hline Ln (RESOURCE) & 0.18 & {$[3.4]^{* * *}$} & 0.20 & {$[3.0]^{* * *}$} & -0.06 & {$[1.7]$} & -0.00 & {$[0.0]$} \\
\hline Ln (MINACAD) & 0.50 & {$[3.1]^{* * *}$} & 0.44 & {$[2.9]^{* *}$} & -0.02 & {$[0.2]$} & 0.14 & {$[1.1]$} \\
\hline Ln (CLNUM) & -0.12 & {$[1.8]^{*}$} & -0.07 & {$[0.6]$} & -0.13 & {$[0.9]$} & -0.25 & {$[1.9]^{*}$} \\
\hline \multicolumn{9}{|l|}{ Teacher pay } \\
\hline Ln (PAY) & 0.05 & {$[0.2]$} & 0.48 & {$[0.8]$} & 0.30 & {$[5.8]^{* * *}$} & 0.18 & {$[2.5]^{* *}$} \\
\hline $\mathrm{N}$ & & \multicolumn{2}{|c|}{542} & \multicolumn{2}{|c|}{360} & \multicolumn{2}{|c|}{360} \\
\hline & \multicolumn{2}{|c|}{0.4307} & \multicolumn{2}{|c|}{0.4306} & \multicolumn{2}{|c|}{0.6375} & \multicolumn{2}{|c|}{0.6339} \\
\hline Sargan $[\mathrm{p}$ value $]$ & & & \multicolumn{2}{|c|}{0.08} & & & \multicolumn{2}{|c|}{0.11} \\
\hline
\end{tabular}


Table 6 Ln (Achievement) For Private Sector Only

\begin{tabular}{|c|c|c|c|c|}
\hline \multirow[b]{2}{*}{ INTERCEPT } & \multicolumn{2}{|c|}{ [1] } & \multicolumn{2}{|c|}{$\overline{[2]}$} \\
\hline & -0.90 & {$[1.5]$} & -0.77 & {$[1.0]$} \\
\hline \multicolumn{5}{|l|}{ Student ability } \\
\hline Ln (SRAVEN) & 0.23 & {$[6.1]^{* * *}$} & 0.25 & {$[7.6]^{* * *}$} \\
\hline \multicolumn{5}{|l|}{ Student attributes } \\
\hline CHAGE/100 & -0.22 & {$[1.6]$} & -0.19 & {$[0.8]$} \\
\hline MALE & 0.15 & {$[4.6]^{* * *}$} & 0.15 & {$[2.9]^{* *}$} \\
\hline CEDASP/100 & 2.89 & {$[2.4]^{* *}$} & 2.93 & {$[1.6]$} \\
\hline HSTUDY/100 & 0.31 & {$[2.5]^{* *}$} & 0.27 & {$[3.0]^{* *}$} \\
\hline TRTIME/100 & 0.01 & {$[0.1]$} & 0.01 & {$[0.1]$} \\
\hline VACWRK & -0.10 & {$[2.3]^{* *}$} & -0.10 & {$[2.1]^{* *}$} \\
\hline TAKESTU/100 & -7.01 & {$[2.3]^{* *}$} & -7.93 & {$[3.9]^{* *}$} \\
\hline NUMSIB/100 & -3.39 & {$[3.2]^{* * *}$} & -3.86 & {$[2.7]^{* *}$} \\
\hline \multicolumn{5}{|l|}{$\underline{\text { Parental attributes }}$} \\
\hline PARHELP/100 & -1.15 & {$[0.4]$} & -2.30 & {$[0.7]$} \\
\hline MEDYRS & -0.03 & {$[0.3]$} & -0.03 & {$[0.3]$} \\
\hline MEDYRSQ/100 & 1.48 & {$[0.3]$} & 2.60 & {$[0.7]$} \\
\hline WEALTH & 0.03 & {$[1.3]$} & 0.04 & {$[1.0]$} \\
\hline WEALTHSQ/100 & -0.22 & {$[0.9]$} & -0.27 & {$[0.8]$} \\
\hline BOOKHOM2 & 0.01 & {$[0.3]$} & 0.01 & {$[0.4]$} \\
\hline воОКНОМ3 & 0.04 & {$[1.1]$} & 0.05 & [1.1] \\
\hline LOWCASTE & -0.04 & {$[0.7]$} & -0.02 & {$[0.3]$} \\
\hline MUSLIM & 0.01 & {$[0.3]$} & 0.01 & {$[0.4]$} \\
\hline \multicolumn{5}{|c|}{ School and teacher quality } \\
\hline JHS & 0.36 & {$[5.2]^{* * *}$} & 0.32 & {$[5.4]^{* * *}$} \\
\hline Ln (DIVISION) & 1.76 & {$[3.3]^{* * *}$} & 1.87 & {$[5.2]^{* * *}$} \\
\hline Ln (RESOURCE) & -0.09 & {$[1.0]$} & 0.001 & {$[0.0]$} \\
\hline Ln (PPMINACAD) & 0.15 & {$[1.1]$} & 0.18 & {$[4.8]^{* * *}$} \\
\hline TOTEXP/100 & 0.26 & {$[0.7]$} & & \\
\hline TRAINING & -0.26 & {$[1.4]$} & & \\
\hline \multicolumn{5}{|l|}{ Teacher pay } \\
\hline $\operatorname{Ln}(\mathrm{PAY})$ & 0.30 & {$[4.6]^{* * *}$} & 0.18 & {$[4.8]^{* * *}$} \\
\hline RESTRICT & & & \multicolumn{2}{|c|}{$0.0022[0.0]^{* *}$} \\
\hline $\mathrm{N}$ & & 60 & \multicolumn{2}{|c|}{360} \\
\hline $\begin{array}{l}\mathrm{R}^{2} \\
\text { Sargan [p value] }\end{array}$ & & 62 & \multicolumn{2}{|c|}{$\begin{array}{l}360 \\
0.63\end{array}$} \\
\hline
\end{tabular}




\section{References}

Alderman, H., J. Behrman, D. Ross, and R. Sabot (1996) "Decomposing the gender gap in cognitive skills in a poor rural economy", Journal of Human Resources, 31(1): 229-55.

Angrist, Joshua, G. Imbens, and D. Rubin (1996) 'Identification of Causal Effects Using Instrumental Variables', Journal of the American Statistical Association, 91 (434):444455.

Angrist, Joshua and Victor Lavy (1999) 'Using Maimonides' Rule to Estimate the Effect of Class-size on Scholastic Achievement”, Quarterly Journal of Economics, 114(3): 104784.

Appleton, Simon (1995) "Exam Determinants in Kenyan Primary Schools: Determinants and Gender Differences", mimeo, McNamara Fellowships Program, World Bank.

Ballou, Dale (1996) “Do Public Schools Hire the Best Teachers?", Quarterly Journal of Economics, 111 (1): 97-133.

Ballou, Dale (2001) "Pay for Performance in Public and Private Schools", Economics of Education Review, 20, pp. 51-61.

Betts, Julian and D. Morell (1999) “The Determinants of Undergraduate Grade Point Average: The Relative Importance of Family Background, High School Resources, and Peer Group Effects", Journal of Human Resources; 34(2), Spring: 268-93.

Boissiere, M., J. Knight and R. Sabot (1985) "Earnings, Schooling, Ability and Cognitive Skills", American Economic Review, 75(2): 1016-30.

Case, Anne and Angus Deaton (1999) "School Inputs and Educational Outcomes in South Africa”, Quarterly Journal of Economics, 114(3): 1047-84.

Fuller, Bruce (1986) "Raising School Quality in Developing Countries: What Investments Boost Learning?”, World Bank Discussion Paper No. 2, World Bank, Washington D.C.

Glewwe, Paul and H. Jacoby (1994) "Student Achievement and Schooling Choice in LowIncome Countries: Evidence from Ghana", Journal of Human Resources; 29(3):843-64.

Govinda, R. and N.V. Varghese (1993) Quality of Primary Schooling in India: A Case Study of Madhya Pradesh, Paris: International Institute for Educational Planning, and New Delhi: National Institute of Educational Planning and Administration (NIEPA).

Hanushek, Eric (1986) "The Economics of Schooling: Production and Efficiency in Public Schools, Journal of Economic Literature, 24(3): 1141-77, September.

Hanushek, Eric, S. Rivkin, and L. Taylor (1996) "Aggregation and the Estimated Effects of 
School Resources, Review of Economics and Statistics; 78(4): 611-27, November.

Hanushek, Eric, J. Kain and S. Rivkin (1999) "Do Higher Salaries Buy Better Teachers?", NBER Working Paper 7082, Cambridge MA.

Kansal, S. M. (1990) "Disparity in Income and Levels of Living Among Teachers in Delhi”, Economic and Political Weekly, 25 No. 46, 17th November: 2547-2554.

Kingdon, Geeta Gandhi (1996a) "Student Achievement and Teacher Pay: A Case-study of India", STICERD Discussion Paper Number 74, London School of Economics.

Kingdon, Geeta Gandhi (1996b) "The Quality and Efficiency of Public and Private Schools: A Case Study of Urban India", Oxford Bulletin of Economics and Statistics, 58, No.1 Feb: 55-80.

Levine, D. (1992) "Can wage increases pay for themselves? Tests with a production function", Economic Journal, September, 102: 1102-1115.

Loeb, Susanna and M. Page (2000) "Examining the Link Between Teacher Wages and Student Outcomes: The importance of alternative Labor Market Opportunities and Nonpecuniary Variation", Review of Economics and Statistics, 82(3): 393-408.

Malcomson, James (1999) "Individual Employment Contracts", in O. Ashenfelter and D. Card, eds. Handbook of labor economics. Volume 3B, pp.2291-2372. New York and Oxford: Elsevier Science, North-Holland.

Mann, P.S. and B. L. Kapoor (1988) "Earnings Differentials between Public, Private and Joint Sectors in Punjab", Journal of Development Studies, 25, No. 1 Oct:97-111.

Papola, T.S. and G. Rodgers (1992) Labour Institutions and Economic Development, International Institute for Labour Studies, Research Series No.97, Geneva: ILO.

Weistroffer, R. (2001) "A merit Pay Allocation Model for College Faculty Based on Performance Quality and quantity”, Economics of Education Review, February 2001, 20 (1): 41-49. 
Appendix: A Note on the Implications of Efficiency Wages

To illustrate the efficiency wage argument for our achievement function simplify the function to the following form:

$A=F(Z, e L)$

where $A$ is achievement, $L$ is labour input augmented by an efficiency term $e$, while $Z$ is a summary variable of all the other factors affecting achievement. If we give this function an explicitly Cobb-Douglas form we have:

$A=Z^{\alpha}(e L)^{(1-\alpha)}$

which can be written as;

Ln $A=\alpha \operatorname{Ln} Z+(1-\alpha) \operatorname{Ln} e+(1-\alpha) \operatorname{Ln} L$

We do not observe effort $e$ but it can be inferred from the profit maximisation conditions.

The profits available to the school are:

$\pi=F(Z, e L)-w L-r Z$

where $w$ and $r$ are the prices of labour and the $Z$ factor.

Efficiency wages implies that $w$ will impact positively on labour effort, hence

$-\pi_{w}=L-F_{e L} L e_{w} \equiv L(1-g)$.

If we have no bargaining then $\pi_{w}=0$ and we get the result that

$F_{e L} e_{w} \equiv 1$

If we now consider the problem of choosing the labour input we will have:

$\pi_{l}=F_{e L} e-w=0$

Combining the expressions for $\pi_{w}$ and $\pi_{l}$ we have:

$w e_{w} / e=1$ which implies $d e / e=d w / w$

With this result we can write our production function as:

$\operatorname{Ln} A=\alpha \operatorname{Ln} Z+(1-\alpha) \operatorname{Ln} w+(1-\alpha) \operatorname{Ln} L$

This result is originally due to Solow and shows that the wage elasticity with respect to effort is unity in this model. While very simple this equation is the basis for some of the early tests of the efficiency wage model, see Levine (1992). 